\title{
Plasma oxytocin and vasopressin concentrations in response to prostaglandin injection into the pig
}

\author{
F. Ellendorff, M. Forsling*, N. Parvizi, H. Williams*, M. Taverne $\dagger$ and \\ D. Smidt \\ Institut für Tierzucht und Tierverhalten, FAL, Mariensee, 3057 Neustadt 1, \\ Federal Republic of Germany; \\ *Department of Physiology, The Middlesex Hospital Medical School, London, U.K. and \\ †Vakgroup Veterinaire Verloskunde, K.I. en Voortplanting, Universiteit Utrecht,
}

The Netherlands

\begin{abstract}
Summary. A single i.m. injection of $5 \mathrm{mg}$ PGF-2 $\alpha$ evoked a significant elevation of plasma oxytocin values in sows 6 days post partum and during dioestrus. Plasma vasopressin levels in dioestrous sows were not significantly affected by PGF-2 $\alpha$. It is concluded that circulating steroid levels do not interfere with the response of oxytocin levels to PGF-2 $\alpha$.
\end{abstract}

\section{Introduction}

A close relationship between oxytocin and prostaglandin (PG) levels has been suggested to exist before parturition (Flint, Forsling, Mitchell \& Turnbull, 1975; Thorburn, Challis \& Currie, 1977), during early lactation (Flint et al., 1975), during the oestrous cycle (Newcomb, Booth \& Rowson, 1977) and in oestrogen-treated anoestrous ewes (Sharma \& Fitzpatrick, 1974). Apart from the work of Gillespie, Brummer \& Chard (1972), who recorded an elevation in plasma oxytocin secretion during infusion of PGs in women, the general approach has been to observe PG concentrations in response to endogenous oxytocin release or oxytocin injection. The hypothesis is that oxytocin-prostaglandin relations exhibit a cascade effect (Thorburn et al., 1977) and provide a rare case of physiological positive feedback that is eventually terminated by a specific event such as parturition or luteolysis (Nathanielsz, 1976).

The present study was designed to answer whether PGs can alter plasma oxytocin levels at times other than just before parturition and whether the response is consistent with a positive or negative feedback.

\section{Materials and Methods}

Animals

Four miniature sows (Göttingen strain, 35-50 kg body weight 6 days after farrowing) and 5 dioestrous Landrace sows (130-150 kg body weight) were kept in single cages with unrestricted access to standard pig diet and water. Indwelling catheters had been inserted into the external jugular vein (Ellendorff, Parvizi, Elsaesser \& Smidt, 1977) at least 4 days before the experiment.

\section{Blood collection}

Blood was generally collected from all animals at 10 -min intervals for up to $240 \mathrm{~min}$ but at 5min intervals from 0-20 min, 60-80 min and 120-140 min (i.e. after the start of the control 
period or following an injection), starting between 09:00 and 10:00 h. Samples of $10 \mathrm{ml}$ blood were obtained from the miniature sows and of $20 \mathrm{ml}$ from the Landrace sows. The samples were collected into chilled heparinized plastic tubes, centrifuged at $4^{\circ} \mathrm{C}$ and the plasma was frozen and stored at $-20^{\circ} \mathrm{C}$. Later, randomly selected samples were analysed from each experimental period and oxytocin and vasopressin were measured in the same sample.

\section{Treatment}

After a control period of $60 \mathrm{~min}$ all sows were given an injection into the neck muscle of $1 \mathrm{ml}$ of the PG diluent $(0.2 \mathrm{ml}$ benzol-ethanol in $20 \mathrm{ml} \mathrm{0.9 \% (w/v)} \mathrm{NaCl})$. At $120 \mathrm{~min}, 1 \mathrm{ml}$ PG solution containing $5 \mathrm{mg}$ PGF-2 $\alpha$ (Dinoprost: Upjohn) was injected i.m. The same dose was given to all animals irrespective of weight, so that the miniature sow received between $0.10 \mathrm{mg}$ and $0.14 \mathrm{mg} \mathrm{PGF}-2 \alpha / \mathrm{kg}$ body weight and the Landrace sows obtained between 0.034 and $0.039 \mathrm{mg} \mathrm{PGF}-2 \alpha / \mathrm{kg}$. Similar dose levels of PGF-2 $\alpha$ (2.5 and $5 \mathrm{mg} / \mathrm{animal})$ are known to induce parturition in sows (Diehl, Godke, Killian \& Day, 1974). A behavioural record was kept throughout the experiment.

\section{Hormone analysis}

Oxytocin. Oxytocin determinations were performed on plasma samples extracted with glass beads as described by Chard \& Forsling (1976) and Forsling et al. (1979). The hormone levels were measured by radioimmunoassay and the pattern of release was confirmed by determination of milk-ejecting activity in selected samples (Chard \& Forsling, 1976). The minimum concentration detectable was dependent on the exact volume extracted, but for the two assays was approximately $0.4 \mu \mathrm{U} / \mathrm{ml}$. The recovery for oxytocin was $59 \pm 2 \cdot 1$ (s.e.m.) $\%, n=12$. The interassay variation was $12.6 \%$ and intra-assay variation was $7.8 \%$. Data were corrected for recovery.

Vasopressin. Vasopressin was determined by bioassay of extracted plasma (Forsling, 1974) in the hydrated rat anaesthetized with ethanol (Forsling, Jones \& Lee, 1968) Synthetic lysinevasopressin (Ferring) was used as the standard. The sensitivity and precision of the assay have been described by Khokhar, Slater, Forsling \& Payne (1976). The recovery was $68 \pm 4.4$ (s.e.m.) $\%, n=6$, and results were corrected for recovery.

\section{Statistical analysis}

All data were treated by analysis of variance followed by Student's $t$ test. Data are expressed as mean \pm s.e.m. and the values obtained within each 60 -min period were pooled.

\section{Results}

As shown in Table 1 and Text-fig. 1, i.m. injections of PGF-2 $\alpha$ result in a surge of oxytocin in sows 6 days after farrowing and during dioestrus. This effect was specific for oxytocin, since vasopressin secretion was not significantly affected during the periods when the PG vehicle and PGF- $2 \alpha$ were injected.

\section{Discussion}

The rise in plasma oxytocin was similar to that observed during parturition of the miniature pig (Forsling et al., 1979) but at parturition progesterone concentrations are at a nadir while plasma oestradiol and oestrone are maximal. In the present experiments a different hormonal situation 
Table 1. Mean \pm s.e.m. plasma oxytocin and vasopressin concentrations in miniature pigs at 6 days post partum and Landrace sows during dioestrus

\begin{tabular}{|c|c|c|c|}
\hline & \multicolumn{2}{|c|}{ Oxytocin $(\mu \mathrm{U} / \mathrm{ml})$} & \multirow{2}{*}{$\begin{array}{c}\text { Vasopressin } \\
(\mu \mathrm{U} / \mathrm{ml}) \\
\text { Dioestrus }\end{array}$} \\
\hline & $\begin{array}{c}6 \text { days } \\
\text { post partum }\end{array}$ & Dioestrus & \\
\hline No. of animals & 4 & 5 & 5 \\
\hline \multicolumn{4}{|l|}{ Sample time (min) } \\
\hline $0-60$ (no treatment) & $1 \cdot 16 \pm 0.25^{a}$ & $0.76 \pm 0.17^{\mathrm{a}}$ & $1.23 \pm 0.23^{a}$ \\
\hline $\begin{array}{l}65-120 \text { (PG vehicle } \\
\text { at } 60 \mathrm{~min})\end{array}$ & $1 \cdot 23 \pm 0.22^{\mathrm{a}}$ & $0.65 \pm 0 \cdot 10^{a}$ & $1.79 \pm 0.38^{\mathrm{a}, \mathrm{b}}$ \\
\hline $\begin{array}{l}125-180(\mathrm{PGF}-2 \alpha \\
\text { at } 120 \mathrm{~min})\end{array}$ & $13 \cdot 37 \pm 1 \cdot 80^{\mathrm{b}}$ & $9 \cdot 69 \pm 2 \cdot 20^{b}$ & $2.58 \pm 0.32^{b}$ \\
\hline $185-240$ & $5 \cdot 44 \pm 1 \cdot 15^{\mathrm{c}}$ & $3 \cdot 35 \pm 0 \cdot 68^{\mathfrak{c}}$ & $1.82 \pm 0.23^{\mathrm{a}, \mathrm{b}}$ \\
\hline
\end{tabular}

Within columns, values with different superscripts are significantly different, $P<0.05$.

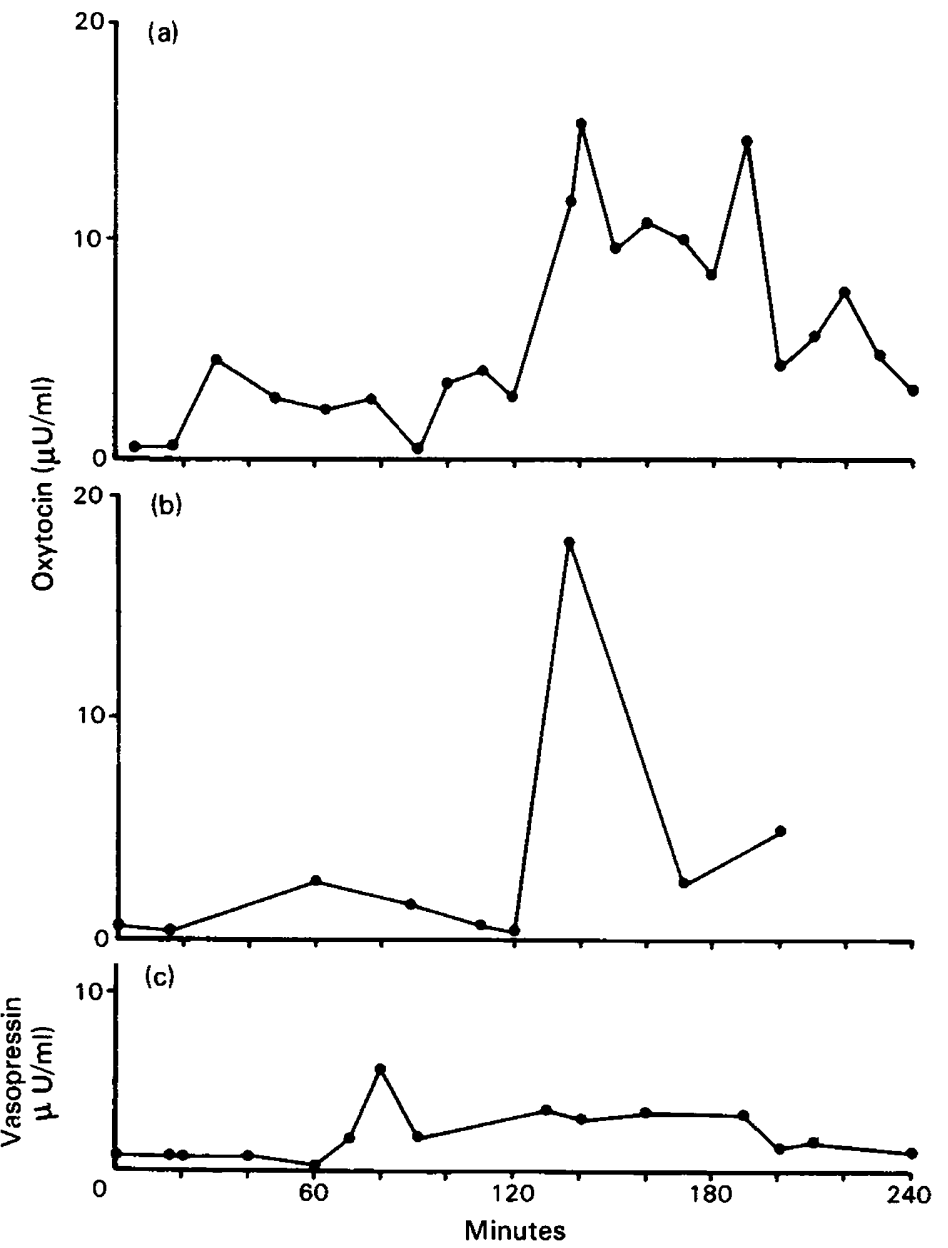

Text-fig. 1. Plasma concentrations of oxytocin ( $a, b)$ and vasopressin (c) after administration of $5 \mathrm{mg}$ PGF-2 $\alpha$ at $120 \mathrm{~min}$ to (a) a miniature sow 6 days post partum, and (b,c) a Landrace sow in dioestrus. The PG solvent was injected at $60 \mathrm{~min}$. 
pertained. After parturition in the pig, plasma progesterone and oestrogen concentrations are close to the lower limit of detection (Ash \& Heap, 1975; Parvizi, Elsaesser, Smidt \& Ellendorff, 1976), but in the dioestrous sow progesterone values are high while oestrogens are present in plasma at comparatively low concentrations (Henricks, Guthrie \& Handlin, 1972). Thus circulating endogenous steroid levels do not inhibit the secretion of oxytocin in response to PGF$2 \alpha$. Roberts \& Share $(1969,1970)$ reported a modifying action of ovarian steroids on the release of oxytocin following vaginal distension in non-pregnant sheep and goats, progesterone being inhibitory, while oestrogen enhanced release. Blank \& de Bias (1977), using a sensitive radioimmunoassay, have confirmed the dose relations of progesterone in the non-pregnant goat and that progesterone transiently facilitates reflex secretion of oxytocin during the summer season when animals are unresponsive, an unresponsiveness which Roberts (1973) tentatively attributed to a failure of the ovaries to secrete oestrogen.

However, it is not clear whether the experimentally induced relationship between PGF- $2 \alpha$ and oxytocin during dioestrus is of any physiological significance. A close relationship between PGs and oxytocin with regard to effect rather than release has been demonstrated: maternal jugular infusion of oxytocin released PGF in uterine venous blood before parturition and in the puerperal sheep (Mitchell, Flint \& Turnbull, 1975). However, Roberts \& McCracken (1976) have indicated that increased uterine synthesis of PGF-2 $\alpha$ is not an essential intermediate step in the activation of the myometrium by oxytocin. PGF and oxytocin may have similar additive functions, i.e. increasing myometrial activity, which results in the expulsion of the fetus or uterine involution as suggested by Flint et al. (1975). The apparently lower plasma oxytocin response seen in dioestrous Landrace sows when compared to miniature sows post partum may be due either to the relatively higher doses (on a body weight basis) administered to the miniature sows or to physiological differences between the post-partum and dioestrous animals. The dose difference when expressed relative to a body weight probably also accounts for the observed differences in behaviour: the miniature sows defaecated and urinated frequently, they bit the cage bars, scratching the floor and were generally restless, the Landrace sows only occasionally defaecated or urinated, but very typically scratched themselves continuously with their hindlegs. Since Bisset, Clark \& Haldar (1970) showed that stress inhibits the milk-ejection reflex even when a stress-induced vasopressin release was observed, we consider it unlikely that a stressful stimulus originating from the PG-injection caused the oxytocin increase. Increased vasopressin concentrations after PGF- $2 \alpha$ treatment could point to a haemorrhagic response to vasopressin due to repeated sampling, but this blood loss, though considerable, did not appear to stimulate vasopressin release as the concentrations actually fell during the final period (Table 1) and were not significantly different from those found initially. It is possible, however, that compensatory mechanisms were brought into play during the first period.

This work was supported by the Deutsche Forschungsgemeinschaft.

\section{References}

Ash, R.W. \& Heap, R.B. (1975) Oestrogen, progesterone and corticosteroid concentrations in peripheral plasma of sows during pregnancy, parturition, lactation and after weaning. J. Endocr. 64, 141154.

Bisset, G.W., Clark, B.J. \& Haldar, J. (1970) Blood levels of oxytocin and vasopressin during suckling in the rabbit and the problem of their independent release. J. Physiol., Lond. 206, 711-722.

Blank, M.S. \& de Bias, D.A. (1977) Oxytocin release during vaginal distention in the goat. Biol. Reprod. 17, 213-223.
Chard, T. \& Forsling, M.L. (1976) Bioassay and radioimmunoassay of oxytocin and vasopressin. In Hormones in Blood, pp. 485-516. Ed. H. N. Antoniades. Harvard University Press, Cambridge, Massachusetts.

Diehl, J.R., Godke, R.A., Killian, D.B. \& Day, B.N. (1974) Induction of parturition in swine with prostaglandin $\mathrm{F}_{2 \alpha^{-}}$J. Anim. Sci. 38, 1229-1234.

Ellendorff, F., Parvizi, N., Elsaesser, R. \& Smidt, D. (1977) The miniature pig as an animal model in endocrine and neuroendocrine studies of reproduction. Lab. Anim. Sci. 27, 822-830. 
Flint, A.P.F., Forsling, M.L., Mitchell, M.D. \& Turnbull, A.C. (1975) Temporal relationship between changes in oxytocin and prostaglandin $F$ levels in response to vaginal distension in the pregnant and puerperal ewe. J. Reprod. Fert. 43, 551-554.

Forsling, M.L. (1974) Extraction of neurohypophysial hormones for bioassay. J. Physiol., Lond. 241, 3-5.

Forsling, M.L., Jones, JJ. \& Lee, J. (1968) Factors influencing the sensitivity of the rat to vasopressin. $J$. Physiol., Lond. 196, 495-505.

Forsling, M., Taverne, M., Parvizi, N., Elsaesser, F., Smidt, D. \& Ellendorff, F. (1979) Release of oxytocin during late pregnancy, parturition and lactation in the miniature pig. J. Endocr. (in press).

Gillespie, A., Brummer, H.C. \& Chard, T. (1972) Oxytocin release by infused prostaglandin. Br. med. J. 1, 543-544.

Henricks, D.M., Guthrie, H.D. \& Handlin, D.L. (1972) Plasma estrogen, progesterone and luteinizing hormone levels during the estrous cycle in pigs. Biol. Reprod. 6, 210-218.

Khokhar, A.M., Slater, J.D.H., Forsling, M.L. \& Payne, N.N. (1976) Effect of vasopressin on plasma volume and urine release in man. Clin. Sci. molec. med. 50, 415-424.

Mitchell, M.D., Flint, A.P.F. \& Turnbull, A.C. (1975) Stimulation by oxytocin of prostaglandin $\mathrm{F}$ levels in uterine venous effluent in pregnant and puerperal sheep. Prostaglandins 9, 47-56.

Nathanielsz, P.W. (1976) Fetal Endocrinology. An Experimental Approach. North-Holland Publishing Company, Amsterdam.
Newcomb, R., Booth, W.D. \& Rowson, L.E.A. (1977) The effect of oxytocin treatment on the levels of prostaglandin $\mathrm{F}$ in the blood of heifers. J. Reprod. Fert. 49, 17-24.

Parvizi, N., Elsaesser, F., Smidt, D. \& Ellendorff, F. (1976) Plasma luteinizing hormone and progesterone in the adult female pig during the oestrous cycle, late pregnancy and lactation, and after ovariectomy and pentobarbitone treatment. $J$. Endocr. 69, 193-203.

Roberts, J.S. (1973) Functional integrity of the oxytocin releasing reflex in goats: dependence on oestrogen. Endocrinology 93, 1309-1314.

Roberts, J.S. \& McCracken, J.A. (1976). Does prostaglandin $F_{2 a}$ released from the uterus by oxytocin mediate the action of oxytocin? Biol. Reprod. 15, $457-463$.

Roberts, J.S. \& Share, L. (1969) Effects of progesterone and estrogen on blood levels of oxytocin during vaginal distention. Endocrinology 84, 1076-1081.

Roberts, J.S. \& Share, L. (1970) Inhibition by progesterone of oxytocin secretion during vaginal stimulation. Endocrinology 87, 812-815.

Sharma, R.C. \& Fitzpatrick, R.J. (1974) Effect of oestradiol-17 $\beta$ and oxytocin treatment on prostaglandin $F$ alpha release in the anoestrous ewe. Prostaglandins 6, 97-105.

Thorburn, G.D., Challis, J.R.C. \& Currie, W.B. (1977) Control of parturition in domestic animals. Biol. Reprod. 16, 18-27.

Received 10 November 1978 